\title{
Teaching the Web 2.0 Generation K.A.Narayan
}

\section{INTRODUCTION}

We are in the midst of a dramatic technological revolution, centered on computer, communication, information, and multimedia technologies. These have been changing the ways people work, communicate with each other and spend their leisure time. This has resulted in a knowledge or information society with education playing a central role. Educators in general and health professional educators in particular, are faced with the challenge of using and deploying these technologies in a creative way. Educators need to rethink their basic tenets and restructure curricula and methods to match these changes.

\section{WHAT ARE THE REVOLUTIONS IN EDUCATION?}

Throughout human history, education has been shaped by the societal needs of the societies in which it is set. Education, after all, is the attempt to convey from one generation to the next the skills, values, and knowledge that are needed for successful life. Education was largely a matter of observing and participating in the work of one's parents, or apprenticing to a local craftsperson.

The first revolution was a more structured and formal form of instruction by a teacher. Knowledge was expressed through stories, legends, folklore, rituals, and songs, without the need for a writing system. Tools to aid this process included poetic devices such as rhyme and alliteration.

The development of writing, starting in about $3500 \mathrm{BC}$, ushered in the second revolution. Various writing systems developed in ancient civilizations around the world. Script was used on stone monuments. Other cursive scripts were used for writing in ink on papyrus. Surfaces used for early writing include wax-covered writing boards, clay tablets,
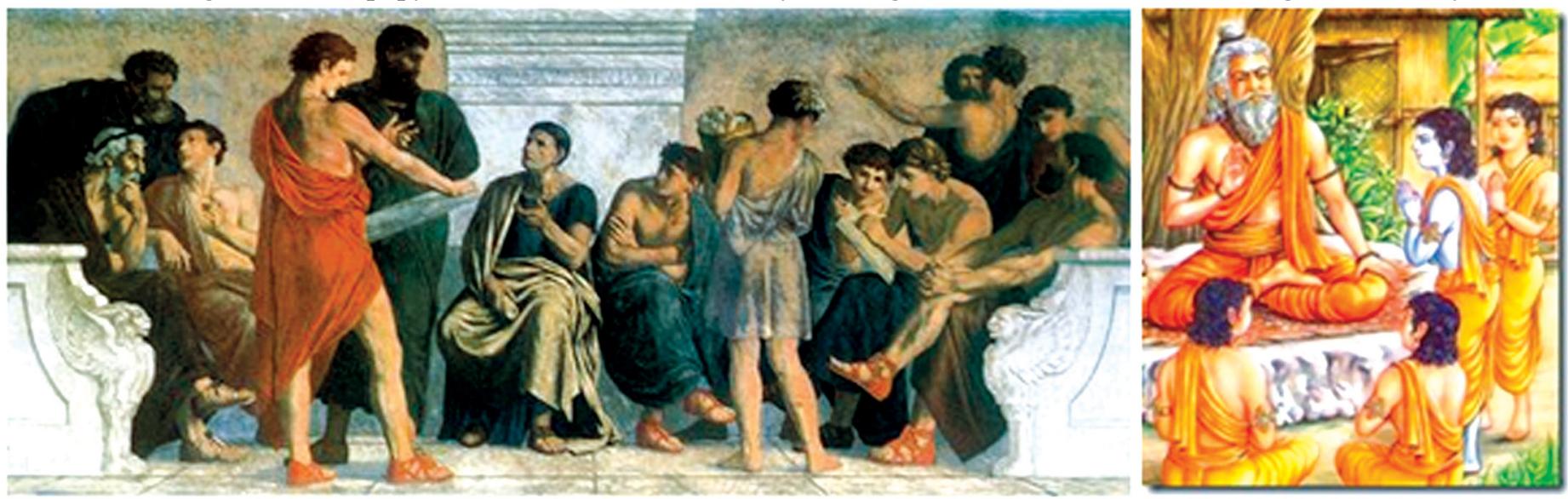

sheets or strips of bark from trees, parchment made of goatskin, vellum, made from calfskin, and wax tablets which could be wiped clean to provide a fresh surface

The development of the printing press in Europe in the last years of the 15th century vastly increased the amount of available reading material. Printing promoted the growth of literacy, and made possible new forms of societal and economic participation within a growing middle class.

The fourth revolution in education occurred early in the twentieth century by a growing understanding of how people learn. The pioneering work of the Russian scientist, Lev Vygotsky, in the 1920s, demonstrated the importance of the social

* K.A. Narayan, MD, DPh, Vice Principal,

MGMCRI and Head of Community Medicine 
environment to the learning process. Jean Piaget, the Swiss psychologist, showed that cognitive development in children proceeded in a predictable sequence of steps. This theory of learning, known as constructivism, had profound implications for the way instruction should be organized. Building from Piaget's work, Bloom formulated his now-famous taxonomy.

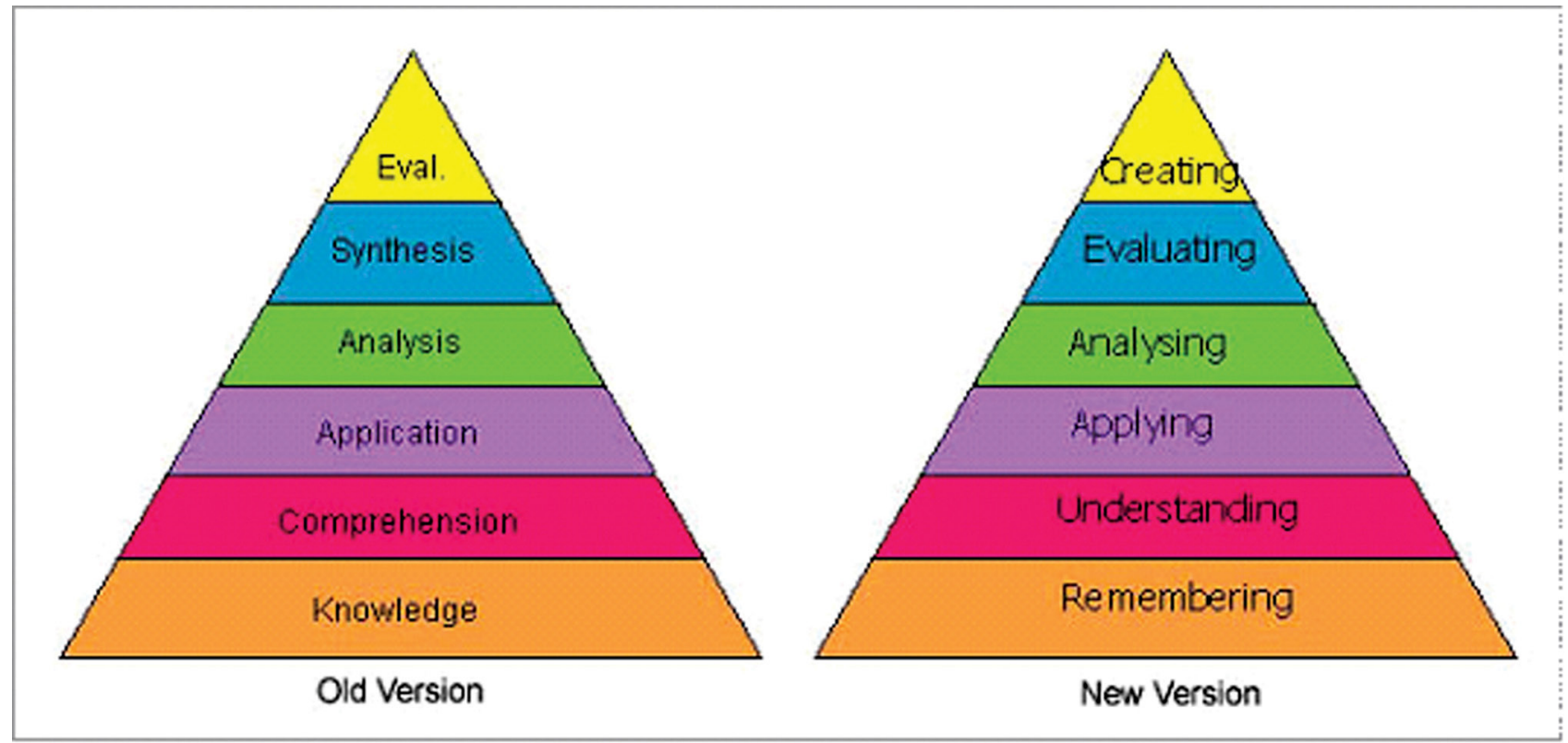

In the 1990s, as a result of the advent of the personal computer and the Internet, virtually every sector of the world economy experienced both profound dislocations and unprecedented opportunities. Geographical and cultural boundaries were broken. The desktop provided tools to teachers to have "user generated content" in text and graphic form. The internet provided a platform to host this content and share it. The biggest value addition was the way that text, and later, images was indexed, made searchable and retrievable. Netscape pioneered the browser which made the content shareable. Google exploited the "user generated" content to offer web search using its "Page rank" algorithm.

The term Web 2.0 which has brought in the current revolution in education, was initially championed by bloggers and by technology journalists, culminating in the 2006 TIME magazine Person of The Year (You). That is, TIME selected the masses of users who were participating in content creation on social networks, blogs, wikis, and media sharing sites. Web 2.0 websites allow users to do more than just retrieve information. By increasing what was already possible in "Web 1.0", they provide the user with more user-interface, software and storage facilities, all through their browser. This has been called "network as platform" computing. Major features of Web 2.0 include social networking sites, user created web sites, self-publishing platforms, tagging, and social bookmarking.

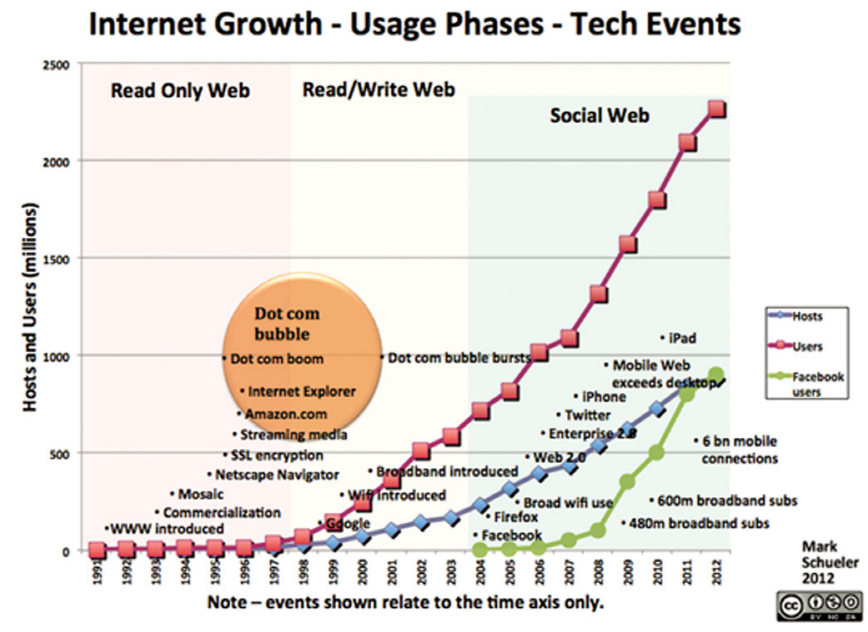




\section{HAVE THERE BEEN CHANGES IN HOW MEDICINE IS TO BE TAUGHT?}

1st generation :

The Flexner Report, a book-length study of medical education in the United States and Canada, written by the professional educator Abraham Flexner and published in 1910 under the aegis of the Carnegie Foundation recommended a science-based curriculum based on scientific research.

\section{2nd generation :}

The PBL-era problem-based instruction which evolved in the 1970's, encouraged self-directed learning skills, placing emphasis on a person's ability to seek out information to tackle a problem at hand. In this approach learners analyze a given clinical scenario, formulate and prioritize key learning objectives within that scenario and then collect whatever additional information they think will be needed to address those objectives. All this takes place within a group setting so that every member of the group contributes to the learning process at every stage.

\section{3rd generation :}

An independent commission of 20 academic leaders from around the world recommended comprehensive reform in the training of healthcare professionals, in a major report published in The Lancet on 4 December 2010. The report called for competency-based curricula, creative use of information technology, transformative learning, and inter-professional teamwork, as well as a systems approach to institutional reforms. The learners are required to

- adapt core competencies to specific contexts

- be systems based to improve the health systems

- draw on global knowledge and expertise

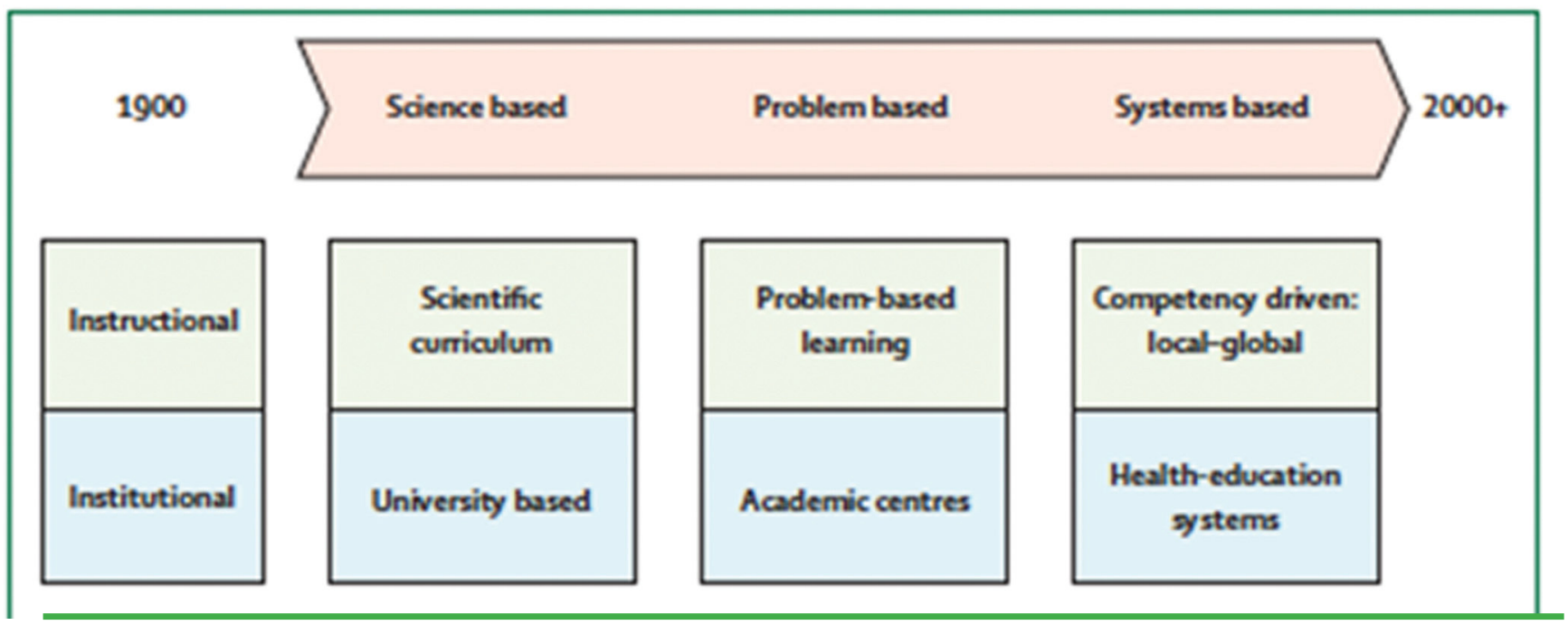

Three generations of Educational Reforms: Informative, Formative, Transformative.

Need to evolve from informative to formative to transformative learning

Informative learning: acquiring knowledge \& skills, to produce 'experts'

Formative learning: values based education, to produce 'professionals'.

Transformative learning: developing leadership attributes, to produce enlightened change agents for healthcare.

How can we globally achieve this is the BIG question.

\section{WHAT ARE THE DIfFERENCES BETWEEN WEB 1.0 AND WEB 2.0?}

Web 1.0 users (consumers) were limited to the passive viewing of content that was created for them. In contrast, a Web 2.0 site allows users to collaborate with each other as creators -"prosumers"- of user-generated content in a virtual community. 
Web 2.0 websites allow users to do more than just retrieve information. By increasing what was already possible in "Web 1.0", they provide the user with more user-interface, software and storage facilities, all through their browser. This has been called "network as platform" computing. Major features of Web 2.0 include social networking sites, user created web sites, self-publishing platforms, tagging, and social bookmarking.

\begin{tabular}{|c|c|c|c|}
\hline & Web1.0 & Web2.0 & $\begin{array}{l}\text { Differences between Web } \\
1.0 \text { and Web } 2.0\end{array}$ \\
\hline Function & Publishing & Participating & $\begin{array}{l}\text { Web } 1.0 \text { : read and } \\
\text { download } \\
\text { Web 2.0: share and upload }\end{array}$ \\
\hline Bookmarker & Directories & Tagging & $\begin{array}{l}\text { Traditionally, expert posses } \\
\text { the right to classify the } \\
\text { resources via the internet. } \\
\text { But in Web } 2.0 \text {, everyone } \\
\text { can decide how to classify } \\
\text { what you want(tag) }\end{array}$ \\
\hline Central Idea & They, the content & We, the content & $\begin{array}{l}\text { In Web 2.0, user defines } \\
\text { and design the content }\end{array}$ \\
\hline User Attitude & Controlled by website & Cooperation Collaboration & $\begin{array}{l}\text { Collaboration also } \\
\text { involves the meaning of } \\
\text { cooperation. } \\
\text { We share knowledge } \\
\text { whenever it is needed } \\
\text { and wherever it is located } \\
\text { through the web } \\
\text { Everyone are both editor } \\
\text { and receiver }\end{array}$ \\
\hline Examples & $\begin{array}{l}\text { Individual large scale } \\
\text { website }\end{array}$ & Blog, wiki & $\begin{array}{l}\text { Web } 2.0 \text { tools are free and } \\
\text { easy to use. }\end{array}$ \\
\hline
\end{tabular}

\section{WHO IS WEB 2.0 GENERATION?}

Gen-Y Teenagers growing up with participatory media known as Web 2.0 social networking, photo- and videosharing, blogging, podcasting, remixing, wikis, user-generated content, online games and social worlds, and so on These have not replaced older media young people still spend more time watching TV than they spend online. Many of them still read printed books! (Ofcom, 2008)

\section{What are the Pros and Cons of Web education?}

Since 2000, the schools raced to connect students to the Internet in broadband. But now, professors urge leaders to "free students from their enslavement to web-2 technology". Why this turn around within a decade? The reasons Web-2.0 Distracts from Class. Students trade stocks, do shopping, and see video clips. They obsessively watch their mobile, i-pad or laptop screens to check for any mails, sms-es, or tweets. During seminars, at any time, 3 of 8 students were browsing on laptops instead of listening to their peers. They think they can multi-task but it hinders their learning. Multi-taskers are not good at switching tasks, ignoring irrelevant information, writing well, using complex ideas/issues. Multi-taskers are more easily distracted \& bored; have short attention span. Multi- taskers are 'socially autistic', less 
emotionally attuned to others. In student centers, they peer at their i-pad screens instead of talking to each other. The solution - ban access by cell phones or wireless. Further the technology may not always be reliable, inefficient for student's time and inappropriate information may become more readily available if certain sites are not blocked (i.e. Youtube)

However it is a powerful educational tool if we attract them - not Ban Web-2. Ban on technology is only a temporary fix. We are ignoring the root of the problem. Ban of the web is more convenient for educators but it is NOT what is best for students. The web can enhance student engagement, improve communications among students and teachers It is a more diverse way for students to connect with other students and teachers, makes learning more interesting to students - visually stimulating. It can enhance exploratory learning, just in time learning, writing and communication skills and creativity.

Want to know how a 21st Century learner learns?

Ask them. You will be amazed at what you hear and if you are smart- you'll act upon it." 7 Solutions for Educators Who Want 21st Century Students to Tune In -by Lisa Nielsen

Ideas for Educators - 1

Problem: Students do web-2.0 instead of listening to the class.

Solutions:

How have you changed your classroom management techniques? Do you let students know when they should and should not open their lap-tops? Do you give a break for them to catch up with web-2.0? Do you make student groups discuss with \& without lap-tops?

Ideas for Educators - 2

Problem:

You are not engaging your web-enabled students

Solutions:

Educators who stand at the front of the room lecturing are not engaging students. Even if they are interested in the topic they can't listen for a long time. Provide accountable interactivity.

e.g., at the end of your lecture have students Tweet relevant thoughts, ideas, and links using a hashtag (\#) provided by you. Raise a question on a blog site for students to answer.

Ideas for Educators - 3

Problem: You complain about technology, but you don't incorporate it into instruction.

Solution:

Teachers could make a Facebook page and use that as a hub for students to connect and share during instruction. Perhaps the teacher sets up some discussion boards or Wall Wishers to share ideas. Many 21st century students aren't content sitting and listening to the teacher. Make your teaching more interesting, and your students will reward you by being more interested. Teachers could adopt Facebook as an effective T-L medium

- 10 Educational Apps for Facebook

o Share Learning Resource Files

o 'Study Hall' - a whiteboard app

o 'Slideshare' - presentation

o 'Flashcardlet' - flashcards to study

o 'Quiz Monster'

o 'Zoho' Online Office

o 'Webinairia' for screencasts

o Book-tag

o To-Do-List

o Skype interface for tele-conference 
- Use groups like Google groups: Users can use groups to more easily:

o Communicate and collaborate with groups of people. For example, groups can be useful for departments, project teams, classes, office locations, special-interest groups, and more.

o Manage access to your documents, sites, videos, and calendars. Users can share their content with groups instead of entering individual addresses. With a group, they can add or remove members once, and the changes are applied to all the Google documents, sites, videos, and calendars that they shared with that group.

- Use a Learning Management System such as MOODLE or DOKEOS

Ideas for Educators - 4

Problem:

Use class time more productively

Solution:

Record your lectures for students to listen to on their own time. This may be in the form of video or a PowerPoint presentation converted to interactive mode with free tools like Wink. Spend class time doing interactive problem solving. Class time can be used for the teacher to help students having difficulty with their work.

Ideas for Educators - 5

Problem:

Are you still trying to be a provider rather than a facilitator of learning?

Solution:

No need to tell students something they can find on the internet

Give them the link and use class time to have discussions, solve problems, or construct their learning.

Extend discussions outside the class room through blogs and wikis.

Incorporate blogs into the classroom as a form of instructional help. With blogs students have a backup place for all kinds of information they need and provide a place for collaboration with other peers on an assignment

Blogs can be used to showcase student's works.

Wikis: Wikis can allow students to collaborate and combine pieces of information and generate pages full of knowledge.

Ideas for Educators - 6

Problem:

You don't own the learning.

The ownership is with your students.

Solution:

If they're not interested in what you say, find out a way to say it that makes them interested. Adopt neuro-linguistic program (NLP technics)

Ideas for Educators - 7

Problem:

Technology is just too distracting for some students

Solution:

A teacher is to help prepare students be successful in their world of the present, not your past.

Remember how Calculators have changed the way maths is taught and assessed.

Is the era of the book over?

Some make the extreme claim that the era of the book and print literacy are over. In the emerging informationcommunication technology environment, traditional print literacy takes on increasing importance. People need to critically scrutinize and scroll tremendous amounts of information, putting new emphasis on developing reading and writing abilities. For instance, Internet discussion groups, chat rooms, e-mail, blogs, wikis, and various Internet forums require writing skills in which a new emphasis on the importance of clarity and precision is emerging. Book and print literacy provide these skills.

What is media literacy?

The current technological revolution, however, brings to the fore more than ever the role of media like television, 
popular music, film, and advertising, as the Internet rapidly absorbs these cultural forms and creates new cyberspaces and forms of culture and pedagogy. With Internet and media culture becoming ubiquitous, it is impossible for educators to ignore these forms of socialization and education. It has become important for teachers to provide media literacy and to discern the nature and effects of media culture.

Media culture is a form of pedagogy that teaches proper and improper behavior, gender roles, values, and knowledge of the world. A media literate person is skillful in analyzing media, criticize stereotypes, values, and ideologies, and competent to interpret the multiple meanings and messages generated by media texts. Media literacy helps people to use media intelligently and to discriminate and evaluate media content.

What are the two views on media literacy?

A traditionalist "protectionist" approach would attempt to "inoculate" young people against the effects of media addiction and manipulation by cultivating a taste for book literacy, high culture, and the values of truth, beauty, and justice, and by denigrating all forms of media and computer culture. This approach would put restriction or bans on usage of devices, $\mathrm{Wi}-\mathrm{Fi}$, media, internet and social networks.

A "media literacy" movement, by contrast, attempts to teach students to read, analyze, and decode media texts, in a fashion parallel to the advancement of print literacy.

What do I need to do to be Web 2.0 savvy?

1) Build out Excuses. Asses where you are with reference to change. Push yourself to the next stage.

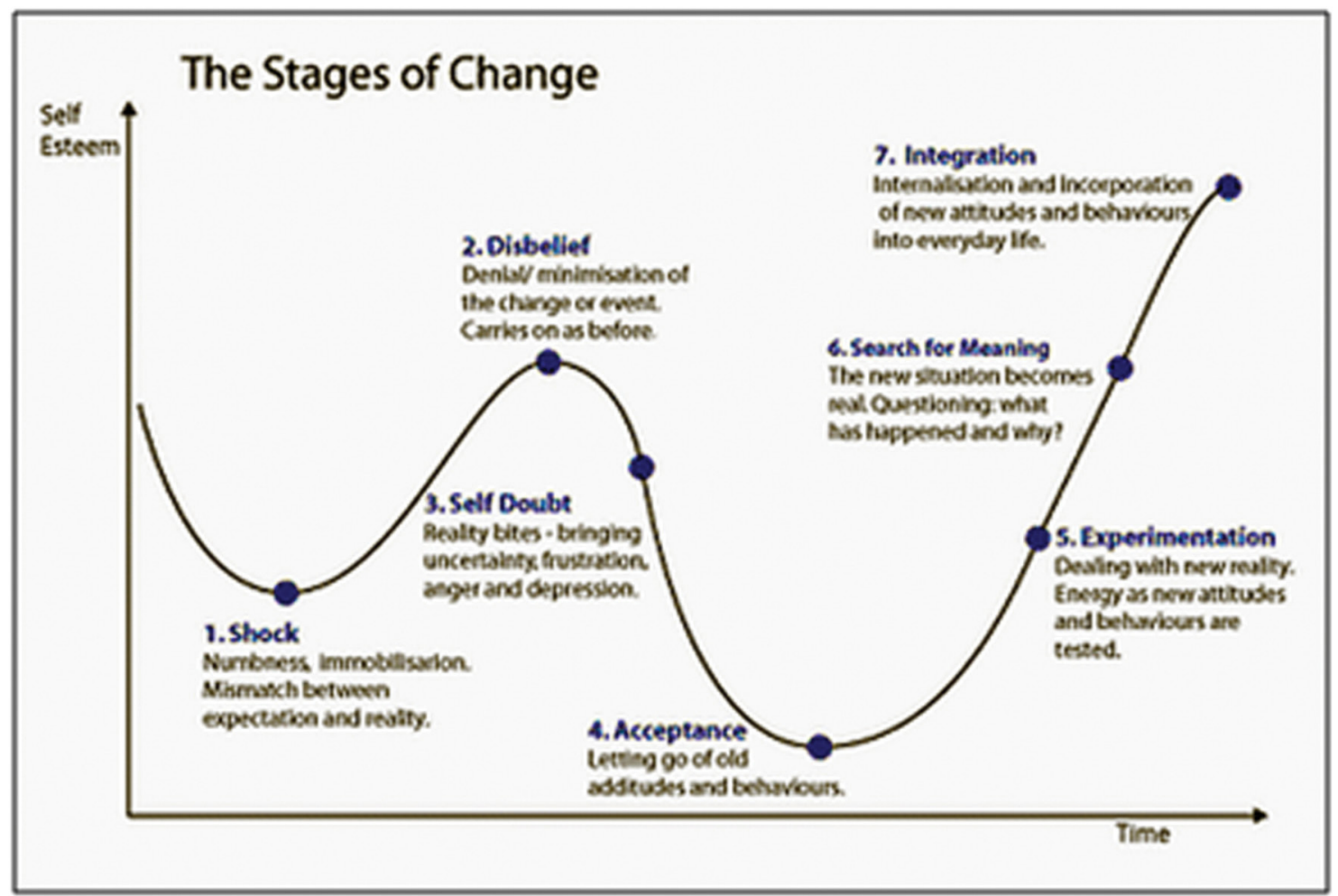

2) The stage of change will match the level of implementation (for any activity)

- No Use

- Awareness

- Exploration

- Infusion

- Integration (Mechanical)

- Integration (Routine)

- Expansion

- Refinement

3) Leading by Being

- I Believe in This

- Transfer of knowledge from one subject area to another seemingly unrelated one. 
- Both being the change and being receptive to change

- Creating epicenters of community learning

- Making information and thinking process secondary and thinking and process primary

- Using the right tool for the right job at the right moment.

- "Realia" make it real and relevant as often as possible.

- Have the passion.

\begin{tabular}{|c|c|}
\hline Web 2.0 Tool for the Classroom & Purpose \\
\hline Glogster & Share images and posters created with fellow students \\
\hline Prezi & Share presentations with PowerPoint \\
\hline Diigo & Popular social bookmarking site \\
\hline Blogger & $\begin{array}{l}\text { Educators and students can collaborate, share } \\
\text { instructional resources, connect to mainstream social } \\
\text { media channels like YouTube }\end{array}$ \\
\hline Voki & $\begin{array}{l}\text { Students share knowledge of a topic in } 60 \text { seconds or less; } \\
\text { great way to have students organize their thoughts to } \\
\text { focus on essential details }\end{array}$ \\
\hline Penzu & Encourages online journaling \\
\hline Skype & $\begin{array}{l}\text { Bring presenters that could not otherwise make it to the } \\
\text { classroom into the room virtually }\end{array}$ \\
\hline Edmodo & $\begin{array}{l}\text { Has the look and feel of Facebook (something that most } \\
\text { students are using in their personal lives)-- educational } \\
\text { perspective, polls, assignments, gradebook, quizzes }\end{array}$ \\
\hline
\end{tabular}

4) Create a Network

Does your network include more than one of the following?

-Microblogging (Twitter, Plurk, etc.)

-RSS Reader

-Social Bookmarking

-Your own blog

-A social networking service (Ning, Facebook, etc.)

5) Have the passion.

Where do i acquire the tools?

If you are still at the Web 1.0 phase

o Introduction to Frontpage

o Frontpage Advanced

o Using Digital Photography in your Classroom

o Podcasting

o Introduction to the Interactive Whiteboard

o Alternate Uses for PowerPoint

o How To use United streaming in Your Classroom

o Windows Movie Maker, parts I and II

o MS Office Ins and Outs

For shifting to Web 2.0

- Administrator's Introduction into Web 2.0

- Tablet Teacher's Toolbox

- Presenting with Google Earth in the Social Studies Classroom

- Introduction to Social Networking and Personal Learning Environments: Using Smarter People to Raise your Level of Thinking

- The Media Rich Classroom: Using Video to Engage and Assess students 
- Feedback Matters: How student feedback can change your lesson design: before, during, and after

- The Wiki Way: Using Wikis as Collaborative Environments

- Internet Safety: What you need to know about keeping your students safe online

- Google Docs and Spreadsheets: Track Student Writing and Foster collaboration through GoogleDocs

- Introduction to Social Networking and Personal Learning Environments: Using Smarter People to Raise your Level of Thinking

o Web 2.0 Teaching Strategies

o Google Docs and Spreadsheets: Track Student Writing and Foster collaboration through Google Docs

o Research 2.0 with RSS: How to get information to Find You

o Copyright or Copy Wrong

o Google School: How to Plan, Implement and Create Using Google for Educators

o Using Wikis to Extend the Walls of your Classroom

o Tablet Teacher's Toolbox

o Using the Wisdom of Crowds to Mine the Web: Social Bookmarking

Points to Ponder for Google-savvy 21st Century Educators...

Since "exams drive student-learning" --

- To assess Problem solving ability, can we adopt 'open-book' or 'open-access' exams where the students can access e-library to solve problems and show their cognitive capacity. There would be no need to ban electronic media and cell phone jammers in the examination hall.

- To assess practical skills, can we adopt portfolio assessment of the learning process and an objective assessment of skills and competencies (OSCE-OSPE)?

The key question is "How do I make the change?"

"If it can be communicated in an email, it doesn't belong in a faculty meeting."

“Great leaders shine brilliant lights away from broken

places to inspire another trek to finer peaks - where

learning captures minds." -Angela Maiers

\section{RESOURCES}

Douglas Kellner: New Technologies / New Literacies:Restructuring Education for a New Millennium.

(http://www.gseis.ucla.edu/faculty/kellner/)

Change in Education - A Letter to my Colleagues

http://21stcenturylearning.typepad.com/blog/2008/06/letter-to-my-co.html

Frenk, Julio, Lincoln Chen, Zulfiqar A. Bhutta, Jordan Cohen, Nigel Crisp, Timothy Evans, Harvey Fineberg, et al. 2010. Health professionals for a new century: transforming education to strengthen health systems in an interdependent world. The Lancet 376(9756): 1923-1958. http://nrs.harvard.edu/urn-3:HUL.InstRepos:4626403 https://sites.google.com/site/childrenseducationweb20/home

History of education http://en.wikipedia.org/wiki/History_of_education

Sethuraman KR TEACHING THE I-PAD GENERATION - Health-Professional Education in the "Web-2.0

Era”. Talk given at Eden Roc, Miami Invited Keynote Address on August 6th, 2011

Patricia Higgins jr. http://www.slideshare.net/pjhiggins/tech-forum-ny08-presentation

Patricia Higgins jr. Making it Happen. How our Imaginations can give us the schools we want. Effective Technology Leadership. http://www.slideshare.net/pjhiggins/tech-forum-ne09

Web 2.0 http://en.wikipedia.org/wiki/Web_2.0

\section{IMAGES}

aristotle:http://commons.wikimedia.org/wiki/File:Spangenberg_-_Schule_des_Aristoteles.jpg

Bloom's Taxonomy: http://epltt.coe.uga.edu/index.php?title=Bloom\%27s_Taxonomy

Wax Tablet: http://historicconnection.webs.com/historyofwriting.htm

VedicSystem: http://www.krishnasmercy.org/dotnetnuke/News/Blog/tabid/57/EntryId/214/Higher-Education.

aspx School of Aristotle, fresco by Gustav Spangenberg. 